\title{
Allocation and productivity of time in new ventures of female and male entrepreneurs
}

\author{
Ingrid Verheul $\cdot$ Martin Carree $\cdot$ Roy Thurik
}

Accepted: 6 January 2009/Published online: 21 February 2009

(C) The Author(s) 2009. This article is published with open access at Springerlink.com

\begin{abstract}
This paper investigates time allocation decisions in new ventures of female and male entrepreneurs using a model that distinguishes between effects of preferences and productivity on the number of working hours. Using data of 1,158 entrepreneurs we find that the preference for work time in new ventures relates to start-up motivation, propensity to take risk and availability of other income. Productivity of work time relates to human, financial and social capital endowments and the prevalence of outsourcing activities. This study also evaluates actual profit effects 1 year after start-up. We find that on average women invest less time in the business than men. This can be attributed to both a lower preference for work time (driven by risk aversion and availability of other
\end{abstract}

I. Verheul $(\bowtie) \cdot$ R. Thurik

Erasmus University Rotterdam,

P.O. Box 1738, 3000 DR, Rotterdam,

The Netherlands

e-mail: iverheul@rsm.nl

I. Verheul · R. Thurik

EIM Business and Policy Research, P.O. Box 7001,

2701 AA Zoetermeer, The Netherlands

M. Carree

Faculty of Economics and Business Administration,

University of Maastricht, P.O. Box 616, 6200 MD

Maastricht, The Netherlands

R. Thurik

Max Planck Institute of Economics,

Kahlaïsche Strasse 10; D-07745, Jena, Germany income) and a lower productivity per hour worked (due to lower endowments of human, social and financial capital).

Keywords Time allocation · Preferences ·

Productivity · Gender · New ventures

JEL Classifications $\quad$ J22 $\cdot$ L26 $\cdot$ M13

\section{Introduction}

Human time is one of the most fundamental resources invested in new ventures. Time allocation theory explains how and why individuals allocate their scarce time to different activities. Since Becker's (1965) “A Theory of the Allocation of Time", a substantial amount of research has been done in this area, mostly focusing on wage or contract labor (Juster and Stafford 1991). Hardly any attention has been paid to the time allocation decisions of the self-employed. The distinction between wage- and self-employment is important because the use of time in these occupations is different in at least two respects. First, self-employed individuals tend to spend more time working in the market than wage-employed individuals (Ajayi-Obe and Parker 2005; Lin et al. 2000), which may relate to greater job satisfaction and higher work demands in self-employment (Hamilton 2000; 
Ajayi-Obe and Parker 2005). Second, self-employed individuals usually have greater flexibility of working hours than wage-employed individuals (Wales 1973; Hyytinen and Ruuskanen 2007).

Research on time allocation decisions of selfemployed individuals usually concentrates on how time is allocated among different activities within the firm rather than how it is divided between the firm and other activities (McCarthy et al. 1990; Cooper et al. 1997). Studies by Lévesque and MacCrimmon (1997) and Lévesque and Schade (2005) deal with the question of how individuals divide their time between leisure and work (in the new venture and wageemployment), but do not perform empirical tests using data of real entrepreneurs. Lévesque and MacCrimmon adopt an analytical approach and introduce a framework for the optimal time allocation between wageand self-employment. Lévesque and Schade investigate time allocation decisions of students in economics and business within an experimental setting.

The present study aims at explaining time allocation decisions of entrepreneurs in new ventures by applying time allocation models from wage labor research to the decision world of the entrepreneur. In addition, we take into account several aspects mentioned in the entrepreneurship literature. Our model explains time investments in new ventures by examining the preference for work time in the firm versus leisure time, the expected productivity of work time and other time-consuming activities (assumed exogenous). The latter include wage-employment, family responsibilities, schooling and commute time (all negatively affecting time invested in the firm). Leisure time is the time available after work time and time spent on the other time-consuming activities. This is the first contribution of the paper: empirically disentangling preference and (expected) productivity effects on time investments in new ventures. This is an important distinction because entrepreneurs allocate their time to the business on the basis of their willingness and ability to work in the firm. Our analysis is based on an extensive and rich data set including time allocation decisions by entrepreneurs.

The second contribution lies in the investigation of gender differences with respect to time allocation decisions. Female entrepreneurs are more likely to work in the firm on a part-time basis than male entrepreneurs (Ajayi-Obe and Parker 2005; Cliff 1998; Verheul and Thurik 2001). The part-time nature of female entrepreneurship has often been explained in terms of household and family responsibilities, but has not been investigated in a setup explicitly distinguishing between preference and (expected) productivity effects. We aim to provide insight into the reasons why women invest less time in the business than men by attributing their lower time investments either to a lower preference for work time or a lower (expected) productivity per time unit. These insights are important as they suggest (new) routes for stimulating participation of women in entrepreneurial activity in terms of working hours. We find that female entrepreneurs, on average, invest less time in the business than men, which can largely be attributed to their lower preference for work time (explained by availability of other income and risk attitude) and a lower (expected) productivity per time unit (explained by relatively lower endowments of human, financial and social capital).

The paper is structured as follows. The next section discusses the literature on the preference for and the productivity of work time. Hypotheses are proposed for the antecedents of both preferences and (expected) productivity. Section 3 describes the sample and variables. Section 4 presents the utility model. The results for preference, productivity and gender effects are given in Section 5. Finally, the summary and conclusion of this paper are presented.

\section{Preferences and productivity}

\subsection{Explaining working hours}

Douglas and Shepherd (2002) distinguish between four factors that determine utility from a job, including income, work effort, risk involved and independence. The first two factors are the traditional input variables in utility models in economic consumer behavior theory (Varian 1984, p. 216). They are also applied to utility-maximizing entrepreneurs (Auster and Silver 1976) where money income $\pi$ and leisure time $L$ determine utility $U(\pi, L)$. This will be the basis for our model. We argue that the variation in the number of working hours across entrepreneurs reflects differences in the preference for working hours or the expected productivity of work time. This is in line with the argument of Douglas and Shepherd (2000) that the decision to become an entrepreneur 
depends upon both the ability to become one and the attitude towards entrepreneurship. Entrepreneurial ability encompasses the knowledge and skills needed to be productive. An individual's attitude reflects the utility (s)he derives from a particular job and the amount of work effort devoted to this job.

\subsection{Antecedents of preference for work time}

This section discusses the determinants of the preference for work time in the newly started venture versus leisure time. Attention is paid to other sources of income, gender, age and intrinsic motivation. Firm-specific factors, having a partner and risk attitude are included in the analysis as controls and will be discussed in the next section.

\subsubsection{Additional income}

Profit is often the main source of income for selfemployed individuals. However, sometimes additional sources of income are available, such as partner income, inheritance and interest received on savings. These sources are not dependent on the number of hours invested in the firm, and there may be an income effect reducing the number of desired working hours. The availability of other income is likely to reduce the preference for working hours (Ajayi-Obe and Parker 2005). Hypothesis 1 is formulated as follows:

H1 The availability of other sources of income (other than that extracted from the business) negatively influences the preference for work time.

\subsubsection{Gender of the entrepreneur}

The average number of working hours per person has decreased considerably in the last hundred years (Maddison 1982, 1987). However, paid working hours for men have declined, whereas for women they have increased substantially (Killingsworth and Heckman 1986). Contemporary time allocation decisions also show gender differences. Employment rates are still lower for women than for men in most OECD countries (OECD 2002), and within any paid occupation men tend to work longer hours than women (Ajayi-Obe and Parker 2005). Men are more likely to work on a full-time basis in self-employment than women (OECD 1998). The combination of work and family responsibilities and flexible working hours seems to be an important motive for women to engage in self-employment (Longstreth et al. 1987). ${ }^{1}$ In the present study, we control for other timeconsuming activities (e.g., wage-employment, family responsibilities, schooling and commute time) and therefore expect no gender difference regarding the preference for work time in the firm. Hypothesis 2 is formulated as follows:

H2 When other time-consuming activities are controlled for, the gender of the entrepreneur does not influence the preference for work time.

\subsubsection{Age of the entrepreneur}

Time allocation decisions depend on age (Juster and Stafford 1991). Market work of men reaches its peak between the age of 25 and 44 years and decreases afterwards (Blinder and Weiss 1976; Hill 1985). Lévesque and Minniti (2006) argue that as people get older, they attach less value to future earnings, i.e., while wages increase with age, the present value of the returns to entrepreneurship declines. Euwals (2001) presents evidence for this negative effect of age on desired working hours for women on the Dutch labor market. Hypothesis 3 is formulated as follows:

H3 The age of the entrepreneur has a negative effect on the preference for work time.

\subsubsection{Intrinsic motivation}

There are various motives for starting a business. Besides the main reason of earning a living (extrinsic motivation), there are non-pecuniary benefits to selfemployment, such as "being one's own boss" and "the challenge" (intrinsic motivation). Hamilton (2000) suggests that the non-pecuniary benefits of selfemployment are substantial. Douglas and Shepherd (2002) refer to independence as a key determinant of the utility derived from a job. Similarly, Hyytinen and Ruuskanen (2007) stress the importance of entrepreneurial independence for job satisfaction of the

\footnotetext{
1 The multiple social roles of women also limit the time they can spend in the business (Nordenmark 2002).
} 
self-employed. It may be expected that entrepreneurs who are intrinsically motivated, e.g., by a desire to be their own boss, work longer hours than entrepreneurs who are largely extrinsically motivated. Hypothesis 4 is formulated as follows:

H4 The start-up motive of being your own boss has a positive effect on the preference for work time.

\subsection{Antecedents of productivity of work time}

Individuals who start new ventures usually are not able to adequately predict (the drivers of) their productivity. So formally we only analyze the role of expected productivity in our utility model. Assuming that individuals are capable of assessing the fruits of their labor and there is at least some overlap between expected and realized productivity, we refer to the literature linking human, social and financial capital to actual productivity to formulate hypotheses on the determinants of expected productivity. In the remainder of this paper, we will just refer to productivity. Firm-specific factors (firm size, sector, innovation, type of firm and outsourcing) are included in the analysis as controls and are discussed in the next section.

\subsubsection{Human capital}

According to human capital theorists (Becker 1965; Mincer 1974), knowledge increases the cognitive abilities of an individual, resulting in more productive and efficient behavior. Indeed, human capital has been found to positively influence the performance of entrepreneurial firms (Chandler and Hanks 1994, 1998; Cooper et al. 1994; Pennings et al. 1998). A distinction can be made between general and specific human capital (Becker 1993). Castanias and Helfat (1991, 2001) discriminate between generic, industryspecific and firm-specific skills or knowledge.

An entrepreneur's education is likely to enhance learning and increase the problem-solving ability of an individual within a given environment. Indeed, several studies find that (formally) higher educated entrepreneurs perform better than others (Gimeno et al. 1997; Hamilton 2000; Burke et al. 2000). ${ }^{2}$ Hypothesis 5 is formulated as follows:

\footnotetext{
${ }^{2}$ Individuals with higher levels of human capital tend to be more self-confident (Davidsson and Honig 2003). Accordingly,
}

H5 The education level of the entrepreneur has a positive influence on the productivity of work time.

Next to the level of education, the type of education could matter for individual performance. Obviously, there is a difference between acquiring general and more specific (job-related) knowledge and skills. Therefore, we distinguish between two types of education: general knowledge acquired in secondary (high) school or at university, and vocational training (professional education). We hypothesize that vocational training has a positive effect on productivity in the new venture since such training may be more directly applicable in the new small venture. Hypothesis 6 is formulated as follows:

H6 Vocational training has a positive influence on the productivity of work time.

According to Cooper et al. (1994, p. 376), gender "may serve as a proxy for life experiences and access to networks and other resources that bear upon the prospects for success of individual entrepreneurs". Although the level of education is largely similar for female and male entrepreneurs (Birley et al. 1987; Fischer et al. 1993), men tend to have higher levels of entrepreneurial experience (Kalleberg \& Leicht 1991; Fischer et al. 1993), financial management experience and industry experience (Fischer et al. 1993; Verheul and Thurik 2001). It has also been argued that women and men do not have equal access to financial and social capital (Fischer et al. 1993; Moore and Buttner 1997). Hence, women may be less productive than men because they had fewer opportunities to acquire different types of capital. Research has shown that women-led firms are outperformed by male-led firms in terms of profits, revenue growth and employment (Rosa et al. 1996; Carter et al. 1997). However, when controlling for the difference in levels of human, social and financial capital (as well as for venture characteristics), we do not expect to

\footnotetext{
Footnote 2 continued

they may have higher expectations of the results of their efforts. Note that some entrepreneurs (about 25\%) have a (parttime) job next to the firm. Hence, human capital may also be deployed as employee, lowering the amount of time available for working in the venture. Still, the large majority of entrepreneurs do not have another job or do not have the opportunity to adjust their working hours in that job.
} 
find gender differences regarding the productivity of work time. In general, research indicates that gender differences in performance are negligible when holding other factors constant (Collins-Dodd et al. 2004; Xie and Shauman 1998; Quisumbing 1996). Hypothesis 7 is formulated as follows:

H7 When the levels of human, social and financial capital are controlled for, the gender of the entrepreneur does not influence the productivity of work time.

The age of the entrepreneur may also be considered a proxy for endowments of human capital, such as years of work or life experience (Gimeno et al. 1997; Cowling and Taylor 2001). Younger people have had less of an opportunity to build up relevant human capital for entrepreneurship. On the other hand, the impact of additional experience is likely to diminish with an increase in age. Several studies show that productivity follows an inverted U-shaped relationship with age (Kanazawa 2003; Skirbekk 2003). Within the area of entrepreneurship, van Praag (1996; 2003) finds that there is a U-shaped relationship of an entrepreneur's age with the hazard of compulsory exit, implying an inverse U-shaped relation with survival. Hypothesis 8 is formulated as follows:

H8 The age of the entrepreneur has an inverse U-shaped relationship with the productivity of work time.

Management-specific knowledge of entrepreneurs increases the probability of pursuing profitable strategies and dealing adequately with management issues (Cooper et al. 1994). It is important to distinguish between management and entrepreneurial experience, the latter referring to experience with starting and running a small firm. In general, entrepreneurship studies find that entrepreneurial experience is a relatively important factor when explaining new venture performance (Stuart and Abetti 1990; Gimeno et al. 1997; Evans and Leighton 1989; Reuber and Fischer 1999), although Westhead and Wright (1998) find a limited effect. Hypothesis 9 is formulated as follows:

H9 Entrepreneurial experience has a positive influence on the productivity of work time.

Entrepreneurs who have worked in the same industry in the past are likely to have a network of relationships with suppliers, customers and distributors, providing them with support and credibility (Cooper et al. 1994). Industry-specific knowledge has proven to be important for new venture performance (Lee and Tsang 2001), even in addition to work and entrepreneurial experience (van Praag 2003). Hypothesis 10 is formulated as follows:

H10 Industry experience has a positive influence on the productivity of work time.

Past work experience of the entrepreneur may be relevant for new firm performance, above and beyond industry experience. According to Vesper (1980), entrepreneurs who run firms that are closely related to the activities they did in the past have acquired relevant skills and abilities as well as the appropriate 'prior mental programming.' van Praag (2003) finds that occupational experience has additional explanatory value for new venture performance, in addition to that of industry, work and entrepreneurial experience. Hypothesis 11 is formulated as follows:

H11 The extent to which past work is related to the current activities of the entrepreneur has a positive influence on the productivity of work time.

\subsubsection{Financial capital}

Financial capital can have a direct effect on productivity through the ability to undertake more capitalintensive or ambitious strategies and to change courses of action. Capital-intensive strategies are relatively well protected from imitation and characterized by increased labor productivity. Indirectly, capital investments may enable training and more comprehensive planning, influencing firm performance (Cooper et al. 1994). Most studies find a positive relationship between initial capital investment and performance (Cooper and Gimeno-Gascon 1992). Hypothesis 12 is formulated as follows:

H12 The amount of start-up capital has a positive influence on the productivity of work time. ${ }^{3}$

\footnotetext{
${ }^{3}$ We assume that the search for financial capital and the decision to invest a certain amount of capital in the new venture precedes the time allocation decision (i.e., how many hours an entrepreneur invests in the business). However, the amount of start-up capital may to some extent be endogenous in the determination of the number of working hours. It is difficult to correct for this within the context of our nonlinear framework.
} 


\subsubsection{Social capital: networking with other entrepreneurs}

Social capital refers to the access of an individual to various resources via interaction with members of a network (Portes 1998; Bourdieu 1986). Such a network may include relationships with family, friends and the community, but also more formal arrangements such as professional or business networks. Interaction and communication within networks of entrepreneurs may contribute to venture performance as it enables the exchange of valuable information and other resources, including customers, suppliers and informal credits (Brüderl and Preisendörfer 1998). Barr (2000) links networks to knowledge flows between firms, influencing firm productivity. Davidsson and Honig (2003) find a strong positive effect of membership in a business network on early stage firm performance. Hypothesis 13 is formulated as follows:

H13 Contact with other entrepreneurs has a positive effect on the productivity of work time.

\section{Sample and variable description}

To test the hypotheses we use data gathered through a detailed panel survey of EIM Business and Policy Research, commissioned by the Dutch Ministry of Economic Affairs. A representative sample was drawn of independent new ventures registered at the Chamber(s) of Commerce in the first quarter of 1994. Only main establishments were selected. The distribution of firms was representative across sector and size class. Agricultural firms and companies extracting minerals, businesses that changed legal form or activity, and relocated firms were excluded. The main themes covered by the survey questions include firm and owner characteristics, finance and investment, bottlenecks, strategy and goals, market and environment, and realization and expectations.

In 1994 approximately 12,000 firms were approached by telephone, of which about 3,000 participated in the survey. These firms received a questionnaire by mail. A total of 1,938 questionnaires was returned. Because firms were also followed in the subsequent year (1995), information is available on time allocation and profits 1 year after start-up. In
1995, 1,007 questionnaires were sent back, resulting in a response rate of about $58 \%$. In this study we use the information for 1994 to test for expected preference and productivity effects, applying a nonlinear model. The information for 1995 is used to test for real productivity effects, explaining profits in 1995.

We use a sub-sample of 1,158 Dutch owners or owner-managers (843 male and 315 female) to test for preference and productivity effects on the number of working hours in 1994. This sub-sample includes all observations for which information is available on the number of working hours in 1994 as well as the characteristics of the business and its owner(manager) relevant for the study. The sample characteristics for the sub-sample of 1,158 entrepreneurs and the total sample of 1,938 entrepreneurs are practically identical. The start-up rate for women is $27 \%$ for the total sample as well as the sub-sample. This is also a representative figure of women starting up firms during the 1990s in The Netherlands. To test for effects on actual profits in 1995, we use a subsample of 561 out of the 1,007 respondents who returned the questionnaire again in 1995 for whom all relevant information (i.e., working hours, side activities, determinants of productivity in the nonlinear analysis) was available.

We include a number of controls. We include dummy variables for a venture in (business and personal) services as well as a business in trade in both the preference and productivity part of the model. The base category is manufacturing and construction firms. The number of employees (measured in full-time equivalents) is also included in both parts of the model. Although our sample mainly consists of start-ups with no or only a few employees, still the entrepreneur with employees is able to delegate some tasks and responsibilities (Churchill and Lewis 1983; Cooper et al. 1997). This might lead to more leisure time or increased productivity.

For the explanation of the preference for work time, we include having a partner and risk attitude. Maintaining a (good) relationship takes time and energy away from the business, but at the same time enables partners to share household tasks resulting in time savings. Because there is no evidence that married men are more productive (Loh 1996), the partner variable is included only on the preference side. We measure risk attitude as the self-reported general willingness of an individual to take risk 
(degree of risk tolerance). ${ }^{4}$ Because entrepreneurial activities are more risky in terms of their outcome than many other activities, relatively risk averse entrepreneurs may limit their work effort (Kihlstrom and Laffont 1979). Nevertheless, Parker (2006, p. 353) argues that risk-averse self-employed workers may have a need for 'self-insurance' and, accordingly, work longer hours. ${ }^{5}$

For the productivity of work time, we include the following controls. The variable ReEntry captures whether the firm is a restart or take-over of an existing firm as opposed to a newly started business. We expect that restarted firms or takeovers will be (more) productive sooner than newly started firms. A de novo firm needs to be built up from scratch, whereas a restarted firm usually already has valuable business relations and knowledge. Innovativeness, outsourcing and commute time are also included as controls. Innovative firms may be more productive than firms that do not pursue product innovation (Crépon et al. 1998; Klomp and van Leeuwen 2001). Nevertheless, Timmons (1986) argues that a high failure rate for innovations is the rule rather than the exception. Astebro (2003) finds that the return to inventions is relatively low, possibly due the unrealistic optimism of inventors. In this study we include a categorical variable indicating the importance of new technology for the firms' products. Outsourcing activities may positively affect productivity (Bettis et al. 1992; D'Aveni and Ravenscraft 1994; Lei and Hitt 1995; Quinn 1992). The entrepreneur will contract out those activities that are most time-consuming, of which (s)he has little experience or that do not belong to the core business. Yet, the empirical evidence that outsourcing activities lead to cost advantages remains limited (Gilley and Rasheed 2000). The variable Commute captures whether the entrepreneur travels to and from the business, i.e., whether (s)he works from the home or in separate business premises. The latter may be an indicator of ambition ("think big"), but may also be an expensive necessity, thereby negatively influencing profitability. ${ }^{6}$

\footnotetext{
$\overline{4}$ This measure is obviously crude, and results for this control variable should be interpreted with care. See also Palich and Bagby (1995).

5 It should be noted that Parker (2006) refers to income risk, whereas this study uses a more general measure of risk aversion.

${ }^{6}$ Carree and Verheul (2004) find a negative effect of the variable HomeBased on expected productivity.
}

Table 1 presents descriptions, means and standard deviations for all variables in the study. The number of working hours per week $(n)$ is categorized from 1 to 7 . The maximum number of hours available per week is assumed to be 100 (i.e., excluding time for personal care), which would correspond to a hypothetical category code of $10 .^{7}$ We fix the maximum number of $N$ at 10 in the nonlinear analysis. The Hours variable has an average of 3.93, indicating an average number of working hours of about $35 \mathrm{~h}$ per week. The mean value for the Hours variable for female and male entrepreneurs is 3.28 and 4.17 , respectively. ${ }^{8}$ On average, men work longer hours than women do. This becomes clear when looking at the gender divide in the highest categories of the Hours variable. Whereas $27 \%$ of all respondents is female, of those who work more than $60 \mathrm{~h}(n=7)$ only $14.5 \%$ is female. This percentage is $17.6 \%$ for the $50-60 \mathrm{~h}$ category $(n=6)$ and $19.5 \%$ for the $40-49$ h category $(n=5)$. Thus, the gender difference increases with the number of working hours.

Table 2 presents correlations between the number of working hours, the independent variables and other time-consuming activities. We see that many variables correlate significantly with working hours, of which StartCapital $(r=0.476 ; P<0.01)$, OtherJob ( $r=-0.440 ; P<0.01)$, OtherIncome $(r=-0.369$; $P<0.01)$ and Commute $(r=0.365 ; P<0.01)$ are most prominent. In general, correlations between the explanatory variables are low. ${ }^{9}$

\footnotetext{
7 The data source Permanent Onderzoek Leefsituatie of Statistics Netherlands (CBS) reports on the time use of Dutch self-employed for 1999 that per day on average $9 \mathrm{~h}$ and $48 \mathrm{~min}$ are used for personal care (sleeping, eating, hygiene). This corresponds to about $68 \mathrm{~h}$ per week. Since a week consists of a maximum of 168 available hours, about $100 \mathrm{~h}$ remain for other (work) activities.

${ }^{8}$ Although the data set stems from 1994, the number of working hours has not changed much over the years. As a comparison, data from the (smaller) 2003 EIM panel of Dutch start-ups show that the average score on the question of the number of working hours is 3.95 , with a female and a male average of 3.33 and 4.22 , respectively.

9 We see some correlation between Commute and StartCapital (r $=0.439 ; \quad P<0.01)$; Similarity and IND experience ( $\mathrm{r}=0.423 ; P<0.01)$; Gender and Family care $(\mathrm{r}=0.375$; $P<0.01)$.
} 
Table 1 Description of variables

Variable name Variable description

Mean SD Mean

Female Male

Dependent

Hours Number of hours invested in the firm in $1994[1=<10 ; 2=10-19 ; 3=20-29 ; \quad 3.93 \quad 2.053 .28$ $4=30-39 ; 5=40-49 ; 6=50-60 ; 7=>60]$

Other time-consuming activities

OtherJob Do you have another (wage) job besides running the business? $[0=$ no; $1=$ yes $]$

FamilyCare Do you have family responsibilities besides running the business? $[0=$ no; $1=$ yes]

Schooling Do you take schooling besides running the business? $[0=$ no; $1=$ yes $]$

Commute Do you have to travel to your work? $[0=$ no; $1=$ yes $]$

Independent variables

OtherIncome Do you or your partner have other sources of income? $[0=$ no; $1=$ yes $]$

Gender

Are you male or female? $[0=$ male and $1=$ female $]$

Age

Age in categories $[1=<20 ; 2=20-24 ; 3=25-29 ; 4=30-34 ; 5=35-39$; $6=40-44 ; 7=45-49 ; 8=50-54 ; 9=55-59 ; 10=>60]$

OwnBoss

Did the wish to be independent play a role in your decision to start your own business? [1 (no); 2 (yes, to some extent); 3 (yes, very important)]

RiskAversion To what extent do you like to take risk [1 = (very high) -5 (very low)]

$\begin{array}{llll}0.28 & 0.45 & 0.26 & 0.29\end{array}$

$\begin{array}{llll}0.10 & 0.30 & 0.28 & 0.03\end{array}$

$\begin{array}{llll}0.06 & 0.24 & 0.10 & 0.05\end{array}$

$\begin{array}{llll}0.21 & 0.41 & 0.19 & 0.21\end{array}$

$\begin{array}{llll}0.74 & 0.44 & 0.84 & 0.70\end{array}$

$\begin{array}{lllll}0.27 & 0.44 & 1 & 0\end{array}$

$\begin{array}{llll}4.61 & 1.76 & 4.48 & 4.69\end{array}$

$\begin{array}{llll}2.47 & 0.70 & 2.52 & 2.47\end{array}$

$\begin{array}{llll}2.22 & 0.80 & 2.33 & 2.16\end{array}$

Education

What is your highest level of education? [ $1=$ low level of education, i.e., low-leve

12 vocational training, average secondary education; $2=$ mid-level education, i.e., higher secondary education, mid-level vocational training, Leerlingstelsel ${ }^{\text {a }}$; 3 = high level of education, i.e., higher vocational training, university]

Vocation Do you have vocational training? $[0=$ no; $1=$ yes $]$

$\begin{array}{llll}0.71 & 0.45 & 0.75 & 0.69\end{array}$

ENTexperience

Did you run a business prior to the start-up of this firm? [0= no; $1=$ yes $]$

$\begin{array}{lll}0.04 & 0.19 & 0.02\end{array}$

0.04

INDexperience

What is the degree of industry experience you have? [ 1 (very weak) -5 (very strong)]

3.89

$0.92 \quad 3.78$

3.93

Similarity

Are your current activities related to past work? [1 (no) to 3 (almost identical)]

2.03

$0.76 \quad 1.86$

2.10

StartCapital

What is the total amount of start-up capital? $[1=<f l .10,000$; $2=f l .10,000-25,000 ; 3=f l .25,000-50,000 ; 4=f l .50,000-100,000 ;$

$5=f l .100,000-250,000 ; 6=f l .250,000-500,000 ; 7=>f l .500,000]^{\mathrm{b}}$

Contacts

Do you have contacts with other entrepreneurs in networks? [1 (never) to 3 (regularly)]

$\begin{array}{llll}2.12 & 1.43 & 1.83 & 2.23\end{array}$

Controls

Partner

Do you have a partner? [0 = no partner; $1=$ partner $]$

Employees

How many employees did you have in $1994 ?^{\mathrm{c}}$

$\begin{array}{lll}1.59 & 0.71 & 1.50\end{array}$

Services

Do you run a service firm? [0= no; $1=$ yes]

$\begin{array}{lll}0.81 & 0.39 & 0.85\end{array}$

0.80

$\begin{array}{llll}0.33 & 1.58 & 0.15 & 0.40\end{array}$

Trade

Do you run a firm in one of the following industries: wholesale, retail, hotels and

$\begin{array}{lll}0.50 & 0.50 & 0.58\end{array}$

0.47 restaurants, repair or transport $[0=$ no; $1=$ yes $]$

ReEntry

Is your firm a takeover or restart of an existing firm? $[0=$ no, it is a new firm; $1=$ yes]

$\begin{array}{lll}0.36 & 0.48 & 0.37\end{array}$

0.35

$\begin{array}{llll}0.14 & 0.35 & 0.13 & 0.14\end{array}$

Outsourcing

Are certain activities within the firm contracted out? $[0=$ no; $1=$ yes $]$

$\begin{array}{lll}0.44 & 0.50 & 0.41\end{array}$

0.45

Innovation

Are your products/services based upon new technology not been used until 3 years ago? [1 (hardly)-4 (almost completely)]

\footnotetext{
a In the 'Leerlingstelsel' students go to school for 1 day a week and work during the rest of the week (that is, a minimum of $20 \mathrm{~h}$ )

b StartCapital is measured in Dutch guilders (florin). One guilder had an average value of 0.62 US dollars in 1995

c Number of employees is measured in terms of full-time equivalents, that is, the number of employees who work more than $32 \mathrm{~h}$ per week
} 


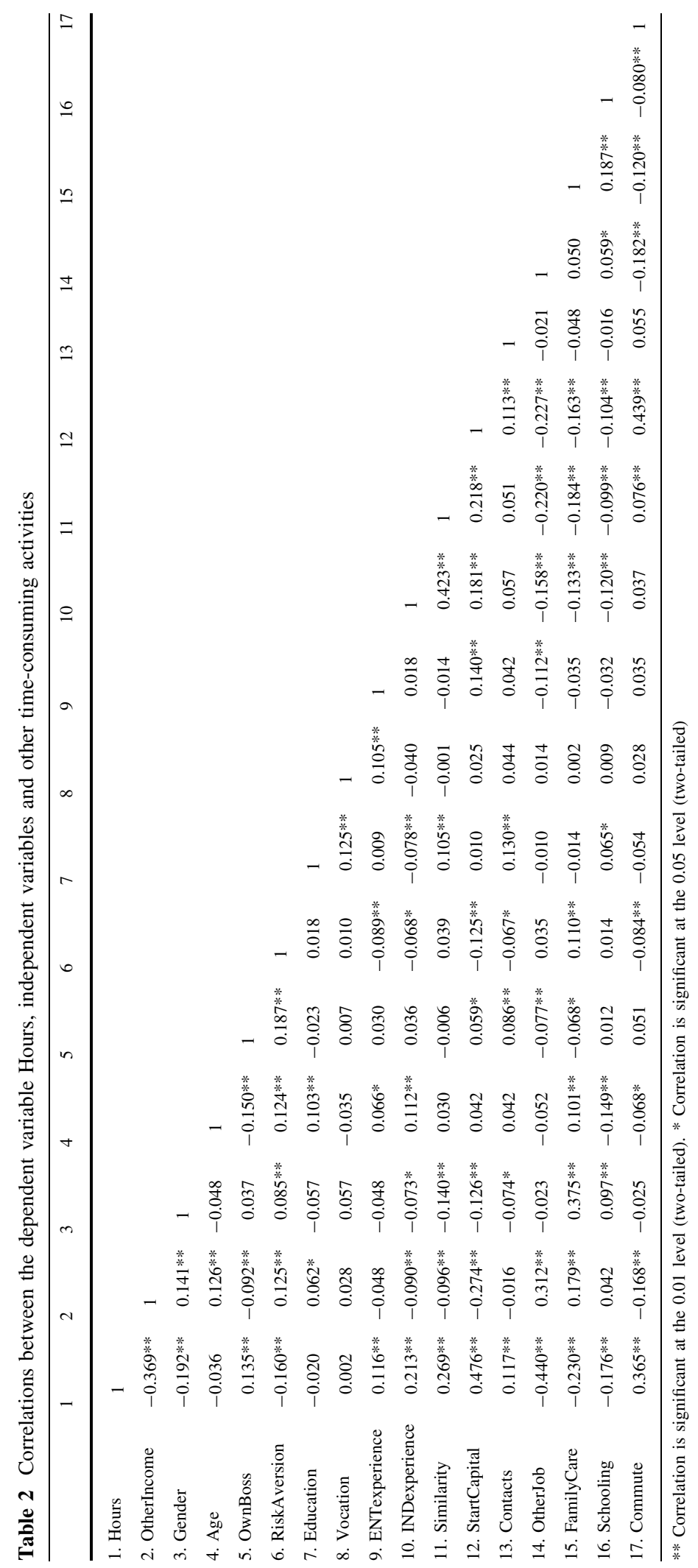




\section{Model and data analysis}

In this study we argue that the number of working hours depends on the preference for work time and the productivity of work time in the firm, which are both again driven by a range of factors. To explain working hours we follow Carree and Verheul (2004) and propose a nonlinear model that includes parameters representing the preference for work versus leisure time $(\alpha)$ and the productivity of work time $(\gamma)$. The model is rooted in economic consumer behavior theory where income (consumption) and leisure determine utility. As we will show, a linear model does not enable us to distinguish between such preference and productivity effects because both effects may underlie the overall effect of a factor on time investments. Therefore, we use a nonlinear analysis based on a maximizing utility setup to disentangle preference and productivity effects on the number of working hours. Finally, to test for the robustness of the expected productivity results from the nonlinear analysis, we examine the actual impact of the productivity antecedents on profits 1 year after start-up. In other words, we compare the outcomes of the nonlinear model (a priori) with the actual impact of the selected variables (a posteriori).

Let $N$ be the total time available per week. We assume that entrepreneurs maximize their utility ${ }^{10}$ : $\operatorname{Max}_{n} U(\pi(n), N-n)$. Utility $(U)$ is influenced positively by expected profit $(\pi)$ and leisure time $(N-n)$. Profit is dependent upon the number of hours worked (n) and expected productivity. We use a CobbDouglas form $U=\pi^{\alpha}(N-n)^{1-\alpha}$ for utility and a profit function $\pi=\beta n^{\gamma}$ and have the following (logarithmic) equations ${ }^{11}$ :

$$
\begin{aligned}
& \ln U=\alpha \ln \pi+(1-\alpha) \ln (N-n) \\
& \ln \pi=\phi+\gamma \ln (n)
\end{aligned}
$$

Note that $\phi=\ln \beta$. We expect that $0<\alpha<1$ and that $\gamma$ is positive. More working hours result in higher profit. The value of $\gamma$ is unknown to the entrepreneur. Therefore, the entrepreneur uses his or her expectation of productivity to determine the optimal value of $n$.

\footnotetext{
10 This is a departure from Lévesque and Schade (2005) who assume bounded rationality in the choice for number of working hours.

11 Thornton (1998) uses a Cobb-Douglas specification to investigate the labor supply of self-employed physicians.
}

The relation between profitability and number of hours is allowed to be non-linear, assuming a possible interdependence between hours and productivity (Barzel 1973).

After substituting the profit function into the utility function, the first-order condition is: $d \ln U / d n=$ $\alpha \gamma / n-(1-\alpha) /(N-n)=0$. The optimal number of working hours for entrepreneur $i$ is therefore:

$n_{i}=\frac{\alpha_{i} \gamma_{i}}{1-\alpha_{i}+\alpha_{i} \gamma_{i}} N$

where $\alpha_{i}$ is the individual-specific preference for profit versus leisure time and $\gamma_{i}$ is the individualspecific hours elasticity of expected profit. The latter can be interpreted as a productivity parameter. Both an increase in $\alpha_{i}$ and $\gamma_{i}$ lead to a higher utilitymaximizing number of working hours. The ratio of the first derivatives of the optimal number of working hours to $\alpha_{i}$ and $\gamma_{i}$ equals:

$\frac{\partial n_{i}}{\partial \alpha_{i}} / \frac{\partial n_{i}}{\partial \gamma_{i}}=\frac{\gamma_{i}}{\alpha_{i}\left(1-\alpha_{i}\right)}$

An entrepreneur can also spend time outside the business, thereby limiting the total time available. We correct for the time an entrepreneur spends on other activities, including wage-employment, family care, schooling and commute time. ${ }^{12} x_{i}$ refers to the presence of other (competing) time-consuming activities of an individual. The final model specification is:

$n_{i}=\frac{\alpha_{i} \gamma_{i}}{1-\alpha_{i}+\alpha_{i} \gamma_{i}}\left(N+\delta x_{i}\right)$

where $\delta$ is expected to be negative. Our dependent variable $n_{i}$ is measured in seven categories. This suggests applying a (nonlinear) order probit analysis. However, such an analysis fails to take into account that the categories are equidistant (with the possible exception of the highest category). Therefore, we also present a nonlinear least squares regression analysis.

\footnotetext{
$\overline{12}$ Male and female entrepreneurs are likely to differ with respect to the time they spend on side-activities. For example, it is well-known that women spend more time on family care than men, as reflected by the gender differential in the mean of the variable Family Care in Table 1 . In this study we focus on the preference for, and the productivity of, time invested in the firm that remains after controlling for other time-consuming activities and obligations. Hence, we do not consider the preference or productivity effect of FamilyCare or that of other side activities.
} 
Fig. 1 Graphic presentation of the model

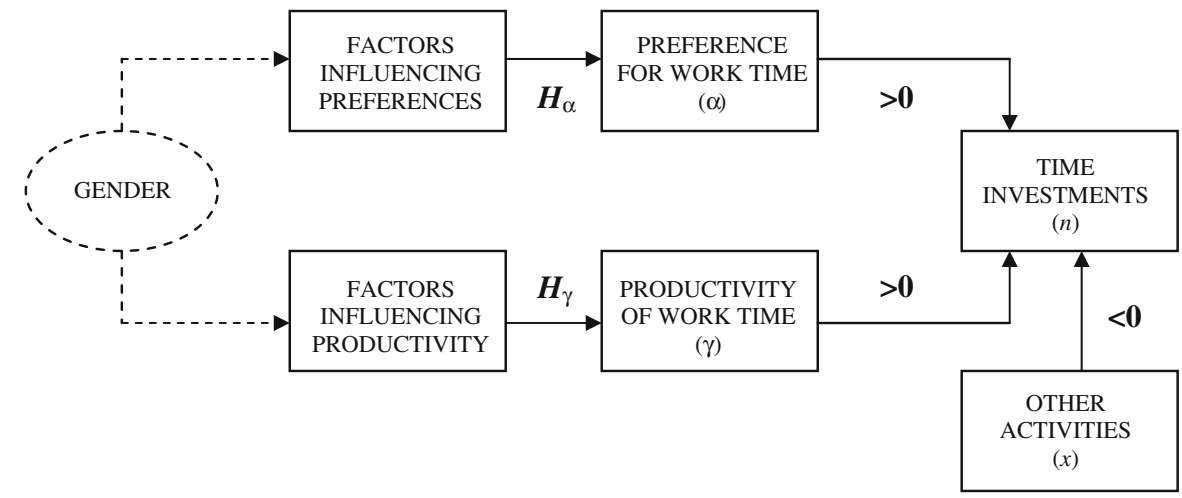

The model predicts a positive productivity effect on the number of working hours. ${ }^{13}$ Generally, an increase in wage or revenues per hour (in the case of self-employment) may lead to an increase or decrease of working hours depending upon whether the 'substitution effect' (whereby individuals substitute leisure for work when returns to work increase) or the 'income effect' (whereby individuals respond to their higher earnings by consuming more leisure at the expense of working hours) dominates (Blundell and MaCurdy 1999). In the empirical literature, findings are inconclusive (Grossman 2003). Ajayi-Obe and Parker (2005) show that in response to higher wages both wage-employed and self-employed individuals work fewer hours. However, Thornton (1998) finds that self-employed male physicians have an upwardsloping labor supply curve. For women results appear more clear-cut. Biddle and Hamermesh (1990) find that higher returns per hour lead to more market work for females. Euwals (2001) finds that the hourly wage positively affects desired hours for females in the Dutch labor market. A possible backward-bending labor supply is more likely at higher hourly wage or productivity rates (Parker 2006, p. 352). Because our sample consists of recently started entrepreneurs with no or only a few employees, it is unlikely that there are predominantly high productivity levels.

The individual-specific preferences $\left(\alpha_{i}\right)$ and productivity $\left(\gamma_{i}\right)$ are influenced by a range of factors. Hypotheses have been formulated for effects on

\footnotetext{
13 An alternative to the Cobb-Douglas specification that allows for both positive and negative productivity effects is a Constant Elasticity of Substitution (CES) specification. However, applying this CES specification we find a range of local optima and unreliable estimates, due to the increased complexity of such specification.
}

preferences $\left(H_{\alpha}\right.$ in Fig. 1) and effects on productivity ( $H_{\gamma}$ in Fig. 1). The preference for working in the firm rather than enjoying leisure time depends on the personal situation of the entrepreneur, including other income available (e.g., partner income), gender, age and start-up motivation. The productivity of work time is expected to be influenced by human, social and financial capital invested in the firm. Individual preferences and productivity are determined by adding up the effects: $\alpha_{\mathrm{i}}=a_{0}+a_{1}$ OtherIncome $_{\mathrm{i}}+$ $a_{2}$ Gender $_{\mathrm{i}}+\ldots$ and $\gamma_{\mathrm{i}}=c_{0}+c_{1}$ Gender $_{\mathrm{i}}+c_{2}$ Age $_{\mathrm{i}}$ $+\ldots$, respectively.

Our model allows for different types of gender effects on time investments. Women may have a different preference for work time than men, leading to a gender difference in time investments. Also, women and men may differ regarding productivity, also leading to different time investments. Below we will call these effects indirect because they run through preference and productivity. Figure 1 assumes that these indirect gender effects are caused by mediation (i.e., other explanatory factors mediate the relationship between gender and preferences or productivity). For example, it may be that women have less entrepreneurial experience than men, negatively affecting their productivity and, accordingly, their time investments.

\section{Results}

In Table 3 we present the results of the different approaches to explaining the number of working hours in the firm $(n)$. In the first two columns we present the results of a linear approximation to Eq. 5: $n_{\mathrm{i}}=\lambda_{0}+$ $\lambda_{1}$ OtherIncome $_{\mathrm{i}}+\lambda_{2}$ Gender $_{\mathrm{i}}+\lambda_{3}$ Age $_{\mathrm{i}}+\ldots$ First, we show the results of the OLS regression and, 
Table 3 Different models explaining Hours and profits

\begin{tabular}{|c|c|c|c|c|c|c|c|}
\hline \multirow[t]{2}{*}{ Variables } & \multirow[t]{2}{*}{ OLS } & \multirow[t]{2}{*}{ Order probit } & \multicolumn{2}{|c|}{ Nonlinear least squares } & \multicolumn{2}{|c|}{ Nonlinear order probit } & \multirow[t]{2}{*}{ Profit } \\
\hline & & & Preference & Productivity & Preference & Productivity & \\
\hline Constant & $2.881 * * *$ & - & 0.5 & 0.086 & 0.5 & 0.665 & $0.604 * *$ \\
\hline OtherIncome & $-0.609 * * *$ & $-0.380 * * *$ & $-0.070 * * *$ & - & $-0.049 * * *$ & - & - \\
\hline Gender & $-0.433 * * *$ & $-0.287 * * *$ & -0.049 & -0.036 & $-0.067 * *$ & 0.337 & $-0.182 * *$ \\
\hline Age & -0.031 & -0.025 & -0.008 & -0.028 & $-0.014 *$ & 0.047 & -0.128 \\
\hline Age sq & -0.001 & 0.000 & - & 0.003 & - & 0.006 & 0.014 \\
\hline OwnBoss & $0.169 * * *$ & $0.136 * * *$ & $0.016 * *$ & - & $0.014 * * *$ & - & - \\
\hline RiskAversion & $-0.142 * *$ & $-0.104 * *$ & $-0.015 * *$ & - & $-0.011 * *$ & - & - \\
\hline Partner & 0.138 & 0.096 & 0.016 & - & 0.009 & - & - \\
\hline Employees & -0.010 & 0.010 & $-0.013 * * *$ & $0.402 * *$ & $-0.012 *$ & 0.990 & $0.035 * *$ \\
\hline Services & $-0.382 * * *$ & $-0.252 * *$ & 0.016 & -0.066 & 0.000 & -0.231 & 0.097 \\
\hline Trade & 0.064 & 0.066 & 0.017 & 0.026 & 0.051 & -0.330 & -0.038 \\
\hline Education & 0.083 & 0.066 & - & 0.051 & - & 0.087 & 0.054 \\
\hline Vocation & -0.045 & -0.031 & - & -0.070 & - & -0.092 & -0.098 \\
\hline ENTexperience & 0.225 & 0.132 & - & 0.134 & - & 0.198 & -0.096 \\
\hline INDexperience & $0.103 *$ & $0.069 *$ & - & $0.051 *$ & - & 0.071 & 0.020 \\
\hline Similarity & $0.199 * * *$ & $0.124 * * *$ & - & $0.102 * *$ & - & 0.150 & $0.089^{*}$ \\
\hline StartCapital & $0.252 * * *$ & $0.181 * * *$ & - & $0.160 * * *$ & - & $0.279 *$ & 0.035 \\
\hline Contacts & $0.138 * *$ & $0.084 *$ & - & $0.064 *$ & - & 0.086 & -0.033 \\
\hline ReEntry & $0.600 * * *$ & $0.434 * * *$ & - & $0.503 * * *$ & - & 0.876 & $0.336 * * *$ \\
\hline Outsourcing & $0.437 * * *$ & $0.296 * * *$ & - & $0.226 * * *$ & - & $0.354 *$ & 0.000 \\
\hline Innovation & 0.036 & 0.027 & - & 0.012 & - & 0.019 & -0.036 \\
\hline Commute $^{\mathrm{a}}$ & $0.534 * * *$ & $0.340 * * *$ & - & $1.047 * *$ & - & $1.644 * *$ & -0.056 \\
\hline OtherJob & $-1.208 * * *$ & $-0.760 * * *$ & \multicolumn{2}{|c|}{$-2.984 * * *$} & \multicolumn{2}{|c|}{$-1.234 * * *$} & - \\
\hline FamilyCare & $-0.323^{*}$ & -0.164 & \multicolumn{2}{|c|}{$-0.806^{*}$} & \multicolumn{2}{|c|}{-0.228} & - \\
\hline Schooling & $-0.701 * * *$ & $-0.461 * * *$ & \multicolumn{2}{|c|}{$-1.938 * * *$} & \multicolumn{2}{|c|}{$-0.811 * * *$} & - \\
\hline Commute $^{\mathrm{a}}$ & - & - & \multicolumn{2}{|c|}{$-1.539 * * *$} & \multicolumn{2}{|c|}{$-0.829 *$} & - \\
\hline $\mathrm{N}$ & 1158 & 1158 & \multicolumn{2}{|l|}{1158} & \multicolumn{2}{|c|}{1158} & 561 \\
\hline $\mathrm{R}^{2}$ & 0.474 & $0.152^{\mathrm{b}}$ & \multicolumn{2}{|c|}{0.498} & \multicolumn{2}{|c|}{$0.161^{\mathrm{b}}$} & $0.260^{\mathrm{b}}$ \\
\hline
\end{tabular}

The dependent variable is Hours for the (non)linear models and the proxy for the logarithm of reported profit in 1995 for the profit model (final column)

$*, * *$ and $* * *$ represent significance at the $0.10,0.05$ and 0.01 levels, respectively (two-sided test)

a Commute is incorporated both as an effect on productivity and as alternative time-consuming activity

b The pseudo $\mathrm{R}^{2}$ is presented here

subsequently, those for the ordered probit regression. In the third and fourth column we present the results of the much richer nonlinear analysis, distinguishing between the preference for work time and the productivity of time. ${ }^{14}$ Again we estimate both a (nonlinear)

\footnotetext{
$\overline{14}$ To ensure identification of the nonlinear regression equation, we fix $a_{0}$ at 0.5 . Altering this value does not substantially affect the results.
}

least squares and an ordered probit regression. We will focus on the least squares results in our discussion.

One can determine the values of the estimated $\alpha_{i}$ and $\gamma_{i}$ by filling in the estimated parameter values for $a_{0}, a_{1}, a_{2}, \ldots$ and $c_{0}, c_{1}, c_{2}, \ldots$ from Table 3 . The average (median) values for $\alpha_{i}$ and $\gamma_{i}$ are $0.41(0.41)$ and 1.44 (1.02), respectively. For women the average (median) values for $\alpha_{i}$ and $\gamma_{i}$ amount to $0.37(0.36)$ and $1.22(0.88)$, respectively, whereas for men they 
amount to $0.43(0.43)$ and 1.53 (1.07), respectively. Hence, on average, female entrepreneurs in the sample have both a lower preference for work time in the firm and a lower productivity of work time than male entrepreneurs. From Eq. 4 we can derive that the effect of $\alpha_{i}$ on $n_{i}$ is about six times the effect of $\gamma_{i}$ on $n_{i}$. This implies that the effect of a gender difference of 0.06 found for $\alpha_{i}$ is approximately equal to that of 0.31 found for $\gamma_{i}$.

\subsection{Linear results}

From the first column in Table 3 we see that the (other) time consuming activities OtherJob, Schooling and FamilyCare negatively affect the number of working hours, whereas Commute has a positive effect. The positive effect of Commute may relate to the fact that firms where the entrepreneur works from home $($ Commute $=0)$ tend to operate on a smaller scale than those established in separate business premises. ${ }^{15}$ The relatively weak effect of FamilyCare may be explained by the fact that family responsibilities can also come at the expense of leisure time (instead of work time). We see that gender has a significant negative effect on the number of working hours, which indicates that ceteris paribus women invest less time in the business than men. Surprisingly, Employees does not influence the number of working hours. Discussing the outcomes of the much richer nonlinear model, we will see that firm size has a negative effect on preferences and a positive effect on productivity, explaining the absence of an overall effect on the number of working hours. This finding underlines the importance of discriminating between preference and productivity effects when studying time allocation decisions.

\subsection{Nonlinear results}

\subsubsection{Preference for work time}

The results of the nonlinear model (estimated both as least squares and ordered probit) are presented in the third and fourth column of Table 3 . We find that the more an entrepreneur is dependent on revenues from

\footnotetext{
$\overline{15}$ For this reason we include Commute as a variable explaining productivity and as a competing time-consuming activity in our nonlinear model.
}

the firm for subsistence, the higher the preference for work time in the business. In addition, individuals who start a business to be their own boss have a higher preference for work time than others. Hypotheses 1 and 4 are supported. There is no separate effect of gender in the nonlinear least squares regression. This would confirm Hypothesis 2. However, the order probit model shows a stronger and significant negative effect of gender on the preference for work time. Apparently, even when controlling for other time-consuming activities, men might more strongly prefer work time over leisure time than women do. The finding that there are fewer 'extremes' among women when it comes to devoting time to their work compared to men is confirmed by research on workaholism (Burke 1999). There is no strong effect of age. Hence, Hypothesis 3 is left with little support. With respect to the controls, we see that the number of employees negatively affects the preference for work time. It appears that entrepreneurs hire more employees to delegate some tasks and responsibilities and, accordingly, work fewer hours themselves. Risk-averse individuals have a lower preference for work time than risk-loving people. New ventures are inherently risky and therefore may be less attractive to risk-averse individuals for investing their time.

\subsubsection{Productivity of work time}

The variable StartCapital has a positive effect on productivity, i.e., investing larger sums of money in the business leads to higher productivity per working hour. In addition, there are positive effects of the degree to which current activities are related to past work (Similarity) and, to some extent (at $10 \%$ level of significance), contact with other entrepreneurs (Contacts) and industry experience (INDexperience). Hypotheses 10 through 13 are supported. In accordance with Hypothesis 7 we find no separate effect of the gender of the entrepreneur on the productivity of work time. We fail to find significant effects of either entrepreneurial experience or age. Hence, there is no support for Hypotheses 8 or 9 . With respect to the controls we find that existing firms (i.e., restarts or takeovers) are characterized by a higher productivity than firms started from scratch. Also, firms that contract out activities are characterized by a higher (expected) productivity than firms that do not engage 
in outsourcing. A firm with more employees has a higher productivity. It seems that having more employees enables effective delegation of activities. Note that Commute is included two times in the model to enable us to disentangle the negative effect of commute time as a competing time-consuming activity, and its positive effect via productivity, possibly reflecting the ambition level of the entrepreneur.

\subsection{Explaining actual profitability}

In our model it is assumed that entrepreneurs are aware of the influence of the various factors on their productivity. The outcomes of the nonlinear model with respect to productivity (a priori) can be compared to the actual impact of the selected variables (a posteriori). This can be done using selfreported profits as the variable to be explained. We perform an ordered probit regression analysis using categorized data on (realized) profits 1 year after start-up (in 1995). Profits are registered as a categorical variable, consisting of 11 categories [numbered 0 to 10: (0) a loss; (1) loss nor profit; (2) profit up to fl. 10,000; (3) profit of fl. 10,000-25,000; (4) profit of fl. 25,000-50,000; (5) profit of fl. 50,000-75,000; (6) profit of $75,000-100,000$; (7) profit of 100,000 150,000; (8) profit of fl. 150,000-250,000; (9) profit of fl. 250,000-500,000; (10) a profit of more than fl. 500,000]. ${ }^{16} \mathrm{Fl}$. (florin) denotes the Dutch guilder, which had an average value of 0.62 US dollars in $1995 .{ }^{17}$ The average value for the profit variable in the sample amounts to 2.75 with a standard deviation of 2.08. The average value for women and men amounts to 2.11 and 2.96, respectively. Hence, on average female entrepreneurs had lower profits than their male counterparts in 1995.

Our analysis is based on Eq. 2. We investigate the impact on the categorical profits variable (used as a proxy for $\ln \pi$ ) of all factors included in the nonlinear analysis explaining productivity $(\gamma)$. We use the number of working hours in 1995 for $n$. Note that the analysis only gives approximate productivity effects, as a proxy variable is used. Because the profit variable is categorical with different ranges of profit across categories, we apply an ordered probit

\footnotetext{
$\overline{16}$ The category "loss nor profit" implies that actual profitability is close to zero.

17 Source: www.jeico.com (consulted on 13 March 2008).
}

regression. Use is made of 561 observations for which data are available on the number of working hours and profits in 1995. Because only a subset of the entrepreneurs answered the profit question 1 year after start-up, there may be some selection bias. Hence, the results should be interpreted as the relationship between hours and profits in 1995 for surviving firms. The final column in Table 3 presents the results for the ordered probit analysis explaining profitability, reporting the components of $\gamma_{i}$ in the profit equation.

Comparing the outcomes of the nonlinear model (estimating expectations of profits) with those of the profit equation (estimating actual profits), we see that entrepreneurial expectations are not completely fulfilled. Although some factors have a relatively similar impact in both models, we identify a difference for others. ${ }^{18}$ More specifically, we find that outsourcing and start-up capital have an impact in the nonlinear model, but disappear in the profit equation. Both outsourcing and capital investment are costly and may not have strong positive effects on profits in the short run (i.e., 1 year after start-up). We see that the effect of commute time disappears in the profit model. This may be explained by the fact that it is relatively costly (or more costly than expected) to operate from a separate business premises, negatively affecting profits. On the other hand, we see that the negative effect of (female) gender becomes significant in the profit model. This may reflect a difference in ambitions of female and male entrepreneurs, where women are more likely to value quality and pursue other goals, not directly related to financial performance (Rosa et al. 1996; Verheul et al. 2002). In the subsequent section gender effects are discussed in detail.

\subsection{Gender effects}

On average men work longer hours than women. The mean value for the Hours variable is 3.28 for women

\footnotetext{
$\overline{18}$ We see that entrepreneurial experience has no significant effect in either the nonlinear or profit model. Although most studies in entrepreneurship acknowledge the importance of experience for firm performance, Metzger (2006) argues that not every experience is an indicator of superior knowledge and that experience of failure may be an indicator of incompetence. Westhead and Wright (1998) find that entrepreneurial experience only has a limited effect on performance.
} 
and 4.17 for men in Table 1. We have also seen that the average preference and productivity is lower for women. This indicates that the lower time investments of women are due to a combination of a lower preference for work time and a lower productivity per hour worked. How can we explain these gender differences? We do not find evidence for (direct) gender effects on either side of the nonlinear model, i.e., when controlled for all other relevant factors we see no significant gender effects on preference or productivity. ${ }^{19}$ This may be an artifact of the model (multicollinearity) and the estimation technique (least squares versus ordered probit), but it appears that the effects of gender are at least partially mediated by other variables. Comparing the mean values for women and men for the explanatory variables (see Table 1) and using chi-square statistics, we find that, when compared to men, women are more likely to have other income available and are more risk averse, and these factors negatively affect the preference for work time. Furthermore, women have less industry experience and are less likely involved in similar activities as in the past; they invest less financial capital and have less contact with other entrepreneurs. These factors have a positive effect on the productivity of work time. Hence, women work fewer hours than men because of a combination of a lower average preference for work time and a lower productivity per hour worked, which can again be explained by the availability of other income and the risk-averse nature of women (for preferences) and lower levels of human, social and financial capital of women (for productivity).

Although we do not find evidence for a (direct) gender effect on productivity in the nonlinear model, we find a negative effect in the profit model. Indeed, also in the linear analysis we have seen that, when controlling for all other explanatory variables and time-consuming activities, there is a negative direct effect of gender on the number of working hours. In these cases gender may serve as a proxy for the effect of an underlying factor that is not included in the

\footnotetext{
19 The lack of statistical significance of the gender effects of -0.049 and -0.036 on preference and productivity, respectively, does not imply that the size of the effect for gender is small. In fact, the combined effect is about equal in size as the effect in the linear model. It only indicates that the model cannot precisely discriminate the two gender effects.
}

analysis. As discussed earlier, a main candidate for the direct gender effect may be the ambition level of the entrepreneur. It may also reflect the fact that women tend to start in different industries than men. Although we correct for the distinction between service and nonservice firms, this is still a relatively crude measure.

\section{Summary and conclusion}

In this study we test for separate preference and productivity effects on the number of working hours in new ventures of female and male entrepreneurs. We choose a nonlinear approach because in a simple linear model this separation can not be made. Findings show that individuals have a lower preference for work time if they have other income available, have employees, are more risk-averse and are not motivated to start a business by 'being one's own boss.' Productivity of time is positively related to financial capital invested, industry and relevant experience, contact with other entrepreneurs, number of employees, running an existing firm, having separate business premises and the prevalence of outsourcing activities. The nonlinear nature of our preference-productivity model allows for separating the effects, though at the expense of increased sensitivity of the estimates.

We find evidence for several gender effects. On average, women invest fewer hours in the firm than men because of a lower average preference for work time and a lower productivity per hour worked. The relationship between gender and both preferences and productivity is mediated by some explanatory factors. The lower female preference for work time can be explained by the availability of other income and the risk-averse nature of women, while the lower female productivity is due to lower levels of human, social and financial capital and the fact that women run relatively small firms. In the linear and profit analyses, we find a negative direct effect of gender on working hours and profit. This 'residual' effect may be attributed to omitted variables. Additional variables could be included in the analysis, capturing goals and ambition levels as well as the nature of family responsibilities, to find out whether the effect is driven by persisting traditional gender roles or is in fact a conscientious choice of women.

The expectations of entrepreneurs about the factors that influence their productivity do not completely 
coincide with their actual impact on profits. Differences between the time allocation and profit model may be explained by a longer time lag between hours invested and profitability, and overconfidence. Judgments of entrepreneurs in new ventures may be subject to overoptimism (Camerer and Lovallo 1999; Busenitz and Barney 1997). For example, the costs of outsourcing or rental of a business premises may outweigh their expected benefits, negatively affecting realized profits.

There are several limitations to the model and variables used in this study. First, the distinction between service, trade and manufacturing/construction firms is relatively crude, and probably does not fully capture industry differences. In addition, the effect of social capital could be studied more indepth, expanding networking to include support from significant others (e.g., family, friends). Another limitation is that the model optimizes time invested in two types of activity: work in the business and leisure. The model could be extended to optimize over time invested in a range of activities, though application is restricted by data availability. The large majority of start-ups in the sample do not have employees. Accordingly, we draw conclusions on the preference for work time and the productivity per time unit mainly for owner-managed new ventures. Finally, we measure work effort in terms of the number of hours allocated to the business, neglecting the fact that a high number of hours does not necessarily imply high work intensity. This could be the case when the entrepreneur spends much time in the business, but does not use this time efficiently. ${ }^{20}$ However, we do investigate productivity of work time in the nonlinear model.

Our analysis suggests that women invest less time in the business than men because of a lower (expected) productivity and a lower preference for work time. This suggests two routes for policy makers to stimulate time investments of women in the business. The first is to influence women's preferences for investing time in the business, for example, by illustrating the excitement and the challenge to run your own business. Secondly, the productivity of women may be enhanced by creating awareness of the importance of relevant experience and knowledge for

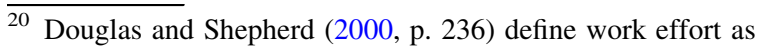
the product of working hours and an index of work intensity. new venture success, advising them to acquire more experience in a wage-job in a similar sector or absorb relevant knowledge and learn from the experiences of successful entrepreneurs. Female entrepreneurs are more likely to ask family members for advice than their male counterparts (Marsden 1987; Greve and Salaff 2003), which may relate to the difficulty of expanding their networks to the male-dominated business circuits (Renzulli et al. 2000).

Acknowledgements The paper has been written in the framework of the research program SCALES carried out by EIM Business and Policy Research (a Panteia company) and financed by the Dutch Ministry of Economic Affairs. Ingrid Verheul acknowledges financial support of the Fund Schiedam Vlaardingen e.o. and the Trust Fund Rotterdam. An early version of the present paper has been read at the Babson Kauffman Entrepreneurship Research Conference, Strathclyde University, Glasgow, Scotland, 3-5 June 2004, and the RENT XVIII Conference, Denmark, Copenhagen Business School, 25-26 November 2004.

Open Access This article is distributed under the terms of the Creative Commons Attribution Noncommercial License which permits any noncommercial use, distribution, and reproduction in any medium, provided the original author(s) and source are credited.

\section{References}

Ajayi-Obe, O., \& Parker, S. C. (2005). The changing nature of work among the self-employed in the 1990s: Evidence from Britain. Journal of Labour Research, 26(3), 501517.

Astebro, T. (2003). The return to independent invention: Evidence of unrealistic optimism, risk seeking or skewness loving? Economic Journal, 113(484), 226-239.

Auster, R. D., \& Silver, M. (1976). Comparative statistics of the utility maximizing firm. Southern Economic Journal, 42(4), 626-632.

Barr, A. (2000). Social capital and technical information flows in the Ghanaian manufacturing sector. Oxford Economic Papers, 52(3), 539-559.

Barzel, Y. (1973). The determination of daily hours and wages. Quarterly Journal of Economics, 87(2), 220-238.

Becker, G. S. (1965). A theory of the allocation of time. Economic Journal, 75(299), 493-517.

Becker, G. S. (1993). Nobel lecture: The economic way of looking at behavior. Journal of Political Economy, 101(3), 385-409.

Bettis, R., Bradley, S., \& Hamel, G. (1992). Outsourcing and industrial decline. Academy of Management Executive, 6(1), 7-22.

Biddle, J. E., \& Hamermesh, D. S. (1990). Sleep and the allocation of time. Journal of Political Economy, 98(5), 922-943. 
Birley, S., Moss, C., \& Saunders, P. (1987). Do women entrepreneurs require different training? American Journal of Small Business, 12(1), 27-35.

Blinder, A., \& Weiss, Y. (1976). Human capital and labor supply: A synthesis. Journal of Political Economy, 84(3), 449-472.

Blundell, R., \& MaCurdy, T. (1999). Labor supply: A review of alternative approaches. In O. Ashenfelter \& D. Card (Eds.), Handbook of Labor Economics (Vol. 3A, pp. 1559-1695). Amsterdam: North-Holland.

Bourdieu, P. (1986). The forms of capital. In J. G. Richardson (Ed.), Handbook of theory and research for the sociology of education (pp. 241-258). New York: Greenwood Press.

Brüderl, J., \& Preisendörfer, P. (1998). Network support and the success of newly founded businesses. Small Business Economics, 10(3), 213-225.

Burke, R. J. (1999). Workaholism in organizations: Gender differences. Sex Roles, 41(5/6), 333-345.

Burke, A. E., FitzRoy, F. R., \& Nolan, M. A. (2000). When less is more: Distinguishing between entrepreneurial choice and performance. Oxford Bulletin of Economics and Statistics, 62(5), 565-587.

Busenitz, L. W., \& Barney, J. B. (1997). Differences between entrepreneurs and managers in large organizations: Biases and heuristics in strategic decision-making. Journal of Business Venturing, 12, 9-30.

Camerer, C., \& Lovallo, D. (1999). Overconfidence and excess entry: An experimental approach. American Economic Review, 89(1), 306-318.

Carree, M. A., \& Verheul, I. (2004) Time allocation by the self-employed: The determinants of the number of working hours in start-ups, Research memorandum, (RM/ 04/022), University Maastricht: METEOR (also forthcoming in Applied Economics Letters).

Carter, N. M., Williams, M., \& Reynolds, P. D. (1997). Discontinuance among new firms in retail: the influence of initial resources, strategy and gender. Journal of Business Venturing, 12(2), 125-145.

Castanias, R. P., \& Helfat, C. E. (1991). Managerial resources and rents. Journal of Management, 17(1), 155-171.

Castanias, R. P., \& Helfat, C. E. (2001). The managerial rents model: Theory and empirical analysis. Journal of Management, 27(6), 661-678.

Chandler, G. N., \& Hanks, S. H. (1994). Founder competence, the environment, and venture performance. Entrepreneurship Theory and Practice, 18(3), 77-89.

Chandler, G. N., \& Hanks, S. H. (1998). An examination of the substitutability of founders' human and financial capital in emerging business ventures. Journal of Business Venturing, 13(5), 353-369.

Churchill, N. C., \& Lewis, V. L. (1983). The five stages of small business growth. Harvard Business Review, 61(3), 30-50.

Cliff, J. E. (1998). Does one size fit all? Exploring the relationship between attitudes towards growth, gender and business size. Journal of Business Venturing, 13(6), 523-542.

Collins-Dodd, C., Gordon, I. M., \& Smart, C. (2004). Further evidence on the role of gender in financial performance. Journal of Small Business Management, 42(4), 395-417.

Cooper, A. C., \& Gimeno-Gascon, F. J. (1992). Entrepreneurs, processes of founding, and new firm performance. In D. L.
Sexton \& J. D. Kasarda (Eds.), The state and art of entrepreneurship (pp. 301-340). Boston: PWS Kent.

Cooper, A. C., Gimeno-Gascon, F. J., \& Woo, C. Y. (1994). Initial human and financial capital as predictors of new venture performance. Journal of Business Venturing, 9(5), 371-395.

Cooper, A., Ramachandran, M., \& Schoorman, D. (1997). Time allocation patterns of craftsmen and administrative entrepreneurs: Implications for financial performance. Entrepreneurship Theory and Practice, 22(2), 123-136.

Cowling, M., \& Taylor, M. (2001). Entrepreneurial women and men: Two different species? Small Business Economics, 16(3), 167-175.

Crépon, B., Duguet, E., \& Mairesse, J. (1998). Research, innovation and productivity: An econometric analysis at the firm level. Economics of Innovation and New Technology, 7(2), 115-158.

D’Aveni, R., \& Ravenscraft, D. (1994). Economies of integration versus bureaucracy costs: Does vertical integration improve performance? Academy of Management Journal, 37(5), 1167-1206.

Davidsson, P., \& Honig, B. (2003). The role of social and human capital among nascent entrepreneurs. Journal of Business Venturing, 18(3), 301-331.

Douglas, E. J., \& Shepherd, D. A. (2000). Entrepreneurship as a utility maximizing response. Journal of Business Venturing, 15(3), 231-251.

Douglas, E. J., \& Shepherd, D. A. (2002). Self-employment as a career choice: Attitudes, entrepreneurial intentions, and utility maximization. Entrepreneurship Theory and Practice, 26(3), 81-90.

Euwals, R. (2001). Female labour supply, flexibility of working hours, and job mobility. Economic Journal, 111(471), C120-C134.

Evans, D. S., \& Leighton, L. S. (1989). Some empirical aspects of entrepreneurship. American Economic Review, 79(3), 519-535.

Fischer, E. M., Reuber, A. R., \& Dyke, L. S. (1993). A theoretical overview and extension of research on sex, gender, and entrepreneurship. Journal of Business Venturing, 8(2), 151-168.

Gilley, K. M., \& Rasheed, A. (2000). Making more by doing less: an analysis of outsourcing and its effects on firm performance. Journal of Management, 26(4), 763-790.

Gimeno, J., Folta, T. B., Cooper, A. C., \& Woo, C. Y. (1997). Survival of the fittest? Entrepreneurial human capital and the persistence of underperforming firms. Administrative Science Quarterly, 42(4), 750-783.

Greve, A., \& Salaff, J. W. (2003). Social networks and entrepreneurship. Entrepreneurship Theory and Practice, 28(1), 1-22.

Grossman, V. (2003). A note on redistributive taxation, labor supply, and national income. International Journal of Business and Economics, 2(1), 39-48.

Hamilton, B. H. (2000). Does entrepreneurship pay? An empirical analysis of the returns to self-employment. Journal of Political Economy, 108(3), 604-631.

Hill, D. H. (1985). The implications of home production and inventory adjustment processes for the time-of-day demand for electricity. In F. T. Juster \& F. P. Stafford (Eds.), Time, goods and well-being (pp. 493-513). Ann 
Arbor: University of Michigan, Institute for Social Research.

Hyytinen, A., \& Ruuskanen, O. (2007). Time use of the selfemployed. Kyklos, 60(1), 105-122.

Juster, F. T., \& Stafford, F. P. (1991). The allocation of time: Empirical findings, behavioral models, and problems of measurement. Journal of Economic Literature, 29(2), 471-522.

Kalleberg, A., \& Leicht, K. (1991). Gender and organizational performance: Determinants of small business survival and success. Academy of Management Journal, 34(1), 136161.

Kanazawa, S. (2003). Why productivity fades with age: The crime-genius connection. Journal of Research in Personality, 37(4), 257-272.

Kihlstrom, R. E., \& Laffont, J. J. (1979). A general equilibrium entrepreneurial theory of firm formation based on risk aversion. Journal of Political Economy, 87(4), 719-748.

Killingsworth, M. R., \& Heckman, J. J. (1986). Female labor supply: A survey. In O. Ashenfelter \& R. Layard (Eds.), Handbook of labor economics (Vol. 1, pp. 103-204). Amsterdam: North-Holland.

Klomp, L., \& van Leeuwen, G. (2001). Linking innovation and firm performance: A new approach. International Journal of the Economics of Business, 8(3), 343-364.

Lee, D. Y., \& Tsang, E. W. K. (2001). The effects of entrepreneurial personality, background and network activities on venture growth. Journal of Management Studies, 38(4), 583-602.

Lei, D., \& Hitt, M. (1995). Strategic restructuring and outsourcing: The effect of mergers and acquisitions and LBOs on building firm skills and capabilities. Journal of Management, 21(5), 835-859.

Lévesque, M., \& MacCrimmon, K. R. (1997). On the interaction of time and money in new ventures. Entrepreneurship Theory and Practice, 22(2), 89-110.

Lévesque, M., \& Minniti, M. (2006). The effect of aging on entrepreneurial behavior. Journal of Business Venturing, 21(2), 177-194.

Lévesque, M., \& Schade, C. (2005). Intuitive optimizing: Experimental findings on time allocation decisions with newly formed ventures. Journal of Business Venturing, 20(3), 313-342.

Lin, Z., Picot, G., \& Compton, J. (2000). The entry and exit dynamics of self-employment in Canada. Small Business Economics, 15(2), 105-125.

Loh, E. S. (1996). Productivity differences and the marriage wage premium for white males. Journal of Human Resources, 31(3), 566-589.

Longstreth, M., Stafford, K., \& Mauldin, T. (1987). Selfemployed women and their families: Time use and socioeconomic characteristics. Journal of Small Business Management, 25(3), 30-37.

Maddison, A. (1982). Phases of capitalist development. Oxford: Oxford University Press.

Maddison, A. (1987). Growth and slowdown in advanced capitalist economies: Techniques of quantitative assessment. Journal of Economic Literature, 25(2), 649-698.

Marsden, P. V. (1987). Core discussion networks of Americans. American Sociological Review, 52(1), 122-131.
McCarthy, A. M., Krueger, D. A., \& Schoenecker, T. S. (1990). Changes in the time allocation patterns of entrepreneurs. Entrepreneurship Theory and Practice, 15(2), $7-18$.

Metzger, G. (2006) Ingredients of growth accounting: Is entrepreneurial experience rich in substance? Paper presented at the 33rd EARIE conference, Amsterdam, 25-27 August 2006.

Mincer, J. (1974). Schooling, experience and earnings. New York: Columbia University Press.

Moore, D. P., \& Buttner, E. H. (1997). Women entrepreneurs: Moving beyond the glass ceiling. London/New Delhi: Sage Publications.

Nordenmark, M. (2002). Multiple social roles-a resource or a burden: Is it possible for men and women to combine paid work with family life in a satisfactory way? Gender, Work and Organization, 9(2), 125-145.

OECD (1998). Women entrepreneurs in small and medium enterprises, OECD Conference Paris 1997. Paris: OECD.

OECD (2002). OECD employment outlook. Paris: OECD.

Palich, L. E., \& Bagby, D. R. (1995). Using cognitive theory to explain entrepreneurial risk-taking: Challenging conventional wisdom. Journal of Business Venturing, 10(6), 425438.

Parker, S. C. (2006). Entrepreneurs as producers. In S. Parker (Ed.), The life cycle of entrepreneurial ventures (pp. 337360). New York: Springer-Verlag.

Pennings, J. M., Lee, K., \& van Witteloostuijn, A. (1998). Human capital, social capital, and firm dissolution. Academy of Management Journal, 41(4), 425-440.

Portes, A. (1998). Social capital: Its origins and applications in modern society. Annual Review of Sociology, 24(1), 1-24.

Quinn, J. B. (1992). Intelligent enterprise: A knowledge and service based paradigm for industry. New York: Free Press.

Quisumbing, A. R. (1996). Male-female differences in agricultural productivity: Methodological issues and empirical evidence. World Development, 24(10), 1579-1595.

Renzulli, L. A., Aldrich, H., \& Moody, J. (2000). Family matters: Gender, networks and entrepreneurial outcomes. Social Forces, 79(2), 523-546.

Reuber, A., \& Fischer, E. (1999). Understanding the consequences of founders' experience. Journal of Small Business Management, 37(2), 30-45.

Rosa, P., Carter, S., \& Hamilton, D. (1996). Gender as a determinant of small business performance: Insights from a British study. Small Business Economics, 8(4), 463-478.

Skirbekk, V. (2003). Age and individual productivity: A literature survey, MPIDR Working Paper \#28. Rostock, Germany: Max Planck Institute for Demographic Research.

Stuart, R. W., \& Abetti, P. A. (1990). The impact of entrepreneurial and management experience on early performance. Journal of Business Venturing, 5(3), 151162.

Thornton, J. (1998). The labour supply behaviour of selfemployed solo practice physicians. Applied Economics, 30(1), 85-94.

Timmons, J. A. (1986). Entrepreneurship and the creation of high-potential ventures. In D. L. Sexton \& R. W. Smilor 
(Eds.), The art and science of entrepreneurship (pp. 223239). Cambridge, MA: Ballinger.

van Praag, C. M. (1996). Determinants of successful entrepreneurship. Amsterdam: Thesis Publishers.

van Praag, C. M. (2003). Business survival and success of young small business owners. Small Business Economics, 21(1), 1-17.

Varian, H. R. (1984). Microeconomic analysis (2nd ed.). New York: W.W. Norton \& Company.

Verheul, I., Risseeuw, P. A., \& Bartelse, G. (2002). Gender differences in strategy and human resource management: The case of the Dutch real estate brokerage. International Small Business Journal, 20(4), 443-476.
Verheul, I., \& Thurik, A. R. (2001). Start-up capital: Does gender matter? Small Business Economics, 16(4), 329-345.

Vesper, K. (1980). New venture strategies. Englewood Cliffs, NJ: Prentice-Hall.

Wales, T. J. (1973). Estimation of a labor supply curve for selfemployed business proprietors. International Economic Review, 14(1), 69-80.

Westhead, P., \& Wright, M. (1998). Novice, portfolio, and serial founders: Are they different? Journal of Business Venturing, 13(3), 173-204.

Xie, Y., \& Shauman, K. A. (1998). Sex differences in research productivity: New evidence about an old puzzle. American Sociological Review, 63(3), 847-870. 